\title{
HOW DID WILLIAM J. MORGAN SHAPE THE ETHICS OF SPORT?
}

\author{
Matija Mato Škerbić \\ Faculty of Croatian Studies, Department of Philosophy and Culture, \\ University of Zagreb, Croatia
}

Original scientific paper

DOI $10.26582 / \mathrm{k} .53 .2 .16$

\begin{abstract}
:
In this paper, I will argue that William J. Morgan had a decisive role in and influence on the shaping of contours and field divisions of the ethics of sport, which is a sub-discipline of the philosophy of sport. In the first part, I will use six Morgan's edited anthologies on philosophy $(1979,1987,1995)$ and ethics of sport $(2001,2007,2017)$ to show that in them, Morgan develops and uses a fourfold division of the fields of the ethics of sport - (1) competition and fair play, (2) human enhancements, (3) gender issues, and (4) social issues. I will also argue that these four fields of Morgan's division have become largely accepted within the discipline as a sort of standard. To provide the rationale for the claim, I will take seven different editions of the ethics of sport, which were most considered and accepted in the field (Parry \& McNamee; R. Simon; J. Boxill; McNamee; Simon, Torres \& Hager). I will show that basically the same field division has been used in them, while the few detected differences are just placing more emphasis on specific topics or issues from Morgan's earlier fourfold division. Moreover, I will use different articles on the topic from sports-philosophical literature to support my claims even further. Also, I will make a claim that the origin of Morgan's division, as well as its strength, derives from the discipline itself or the course of the development that discipline has taken from the beginning. In the end of this part, I will deal with possible anticipated objections. In the final part, I will provide a critical overview of the Morgan's division, point out detected problems and provide possible solutions.
\end{abstract}

Key words: William John Morgan, ethics of sport, contours and fields divisions

\section{Introduction}

The very first piece from William John Morgan within the Philosophy of Sport literature dates from 1973 in R. Osterhoudt's The Philosophy of Sport. A Collection of Original Essays. From this point on, until 2020, he has published more than 60 articles, conference proceedings and reviews, eight edited books and three authors books. He has made different contributions to the development and recognition of the discipline not only through his published work, most of it recognised and presented in the festschrift (JPS, 12, 4, 2018), but also through serving as an editor of Journal of the Philosophy of Sport and president of the International Association for the Philosophy of Sport (IAPS), among others.

Morgan's influence in the field of Philosophy and Ethics of Sport is basically twofold - "internal" and "external". On one hand, his "inner" contributions confirm him as one of the deepest thinkers in the discipline, and perhaps the two most important are the internalist conception and MacIntyre's insights on the social practice in the philosophical/ ethical discourse (Morgan, 1987, 1994). On the other hand, among "external" contributions, his work as an editor, president, and promoter of the discipline stands out. He was making the space for a new discipline in the larger realm of general Philosophy and Ethics, generating the interest among scholars, and for the initiation of the studies and courses at the universities around the globe. Also, he was creating the outer contours of the discipline and making divisions of the fields, through compiling, editing, and choosing the topics and works, pointing out crucial contributions and contributors.

My focus in this paper will be at the latter - the field divisions that Morgan was making within his six edited anthologies, which he has been continuously publishing for decades (1979, 1987, 1995, 2001, 2007, 2017), and he still does. My aim is to produce enough solid rationales for my claim that Morgan has shaped the contours and divisions of the ethics of sport.

My plan is the following. In order to create a proper context, I will firstly introduce a short 
history of the sub-discipline and point out its key points. Secondly, I will present Morgan's (development of) fourfold division. Thirdly, I will use what I believe to be the seven most accepted anthologies within the field, namely: Boxill (2003), McNamee (2010), McNamee and Parry (1998), Simon (1991, 2004, 2010), and Simon, Torres, and Hager (2015), to show that the very similar division was used in all of them, with a few differences that does not influence my general claim. Fourthly, I will deal with four groups of possible objections to my claims and interpretations. Finally, I will provide a few critical notes on Morgan's division.

\section{Ethics of sport - the look back}

Philosophy of sport as a discipline started in $1972^{1}$. Ethical considerations of sport were undertaken at the very beginning of the disciplinary phase of the Philosophy of Sport in 1972. In the same year, one of the four 1972 foundational symposiums (Brockport, Ontario, Munich, Brockport) was held at the State University College Brockport, New York (26-28 October) dedicated to sport and ethics. Furthermore, in the Ellen Gerber's (1972) and Robert Osterhoudt's (1973) editions, the very first in the new discipline, 'value-oriented concerns in sport' and questioning the ethical status of sport got their own book chapters, while in the third issue of the Journal of the Philosophy of Sport (1976) first articles were published by W. J. Morgan on J. P. Sartre's ethics of ambiguity and R. Osterhoudt on I. Kant's categorical imperative and G. W. F. Hegel's Sittlichkeit.

The first systematic ethical consideration of sport took place in the 1980s on the topic of doping in sport, with the contributions from W. Fraleigh, W. M. Brown and R. Simon, among others. Two confronted positions were developed, libertarian and essentialist, over five arguments: nature, unfair advantage, paternalism, coercion, and harm. Furthermore, in his 1984 book Right Actions in Sport. Ethics for Contestants Warren Fraleigh has built practical guidelines for sportsmen in sports competitions. Fraleigh's book is probably the first genuine philosophical concept within the discipline that is almost not at all leaning on the previous philosophical (or sports-philosophical) literature. Hence, he is mentioning only 14 authors (eight sports-philosophers - Kretchmar, Morgan, Metheny, Osterhoudt, Delattre, McIntosh, Suits, McBride), leaning actually on one - Kurt Baier, and his book The Moral Point of View (1958). Fraleighs' book made an impact on the community and initiated the interest among scholars. It seems to me that this could be perceived as the starting point of the ethics of sport as a separated discipline.

In the 1990s, ethics of sport became central (McNamee \& Morgan, 2015: 132; McNamee, 2007: 3 ) and most vibrant (McNamee, 2003, 182) field of philosophy of sport. Many articles were published in that period, as well as different (edited) books. (Lumpkin, Stoll, \& Beller, 1994; McNamee \& Parry, 1998; Simon, 1991; ...)

In the 2000s, two crucial steps in promoting and developing the ethics of sport as a separated field were conducted by two British scholars - Mike McNamee and Jim Parry. The first step was the initiation of the Routledge book-series 'Ethics and Sport' in 1998, with more than 30 published books until 2020. The second was starting the journal Sport, Ethics and Philosophy in 2008 with focus on ethical issues in sport, introducing many new topics and approaches, as well as new scholars mostly gathered around British Philosophy of Sport Association (BPSA). The journal has almost immediately become a leading global sports-philosophical journal, side by side with Journal of the Philosophy of Sport.

Finally, during the last more than a decade, the field of normativity has become significantly interesting and important topic. Debate between (broadpluralistic) internalists, such as B. Simon and J. Russell, and (historicistic-ethnocentric) conventionalists such as B. Morgan, somehow marked the period, and raised interest and involvement of many scholars (Scott Kretchmar, J. F. Lopez Frias, M. McNamee, E. Moore, S. N. Dixon, S. MacRae, D. Hyland, and D. T. Durbin). On the other hand, the rushing biomedicine technology development brought many questions and opened up many discussions in the field about the present and the future of the sport and its integrity.

\section{W. J. Morgan's fourfold division}

Through editing his books for more than three decades, Morgan has developed and presented his fourfold field division within the ethics of sport: 1) competition; 2) enhancements; 3) gender; and 4) social issues in contemporary sports.

The first anthology that Morgan edited was the $2^{\text {nd }}$ edition of 'Sport and the Body. A Philosophical

\footnotetext{
At the $2^{\text {nd }}$ International Conference Ethics, Bioethics and Sport in Croatia (22 nd and $23^{\text {rd }}$ March, 2019, Zagreb and Varaždin) I presented my model of History of the Philosophy of Sport in the paper titled "The Early Philosophy of Sport: Investigations in the History of the Discipline", where I divided it into three phases: (1) Ancient Phase (Homer, Plato, Aristotle), (2) Pre-disciplinary Phase (history of philosophy relevant for philosophy of sport and theory of sport in the 19th century that led directly into Philosophy of Sport), and (3) Disciplinary Phase (starting in 1972 with the first symposiums and establishment of the PSSS). Namely, in 1972, philosophy of sport became official philosophical discipline by helding its first specific symposiums (Munich, New York, Ontario, New York) and establishing specific association (Philosophic Society for the Study of Sport), accompanied with issuing a journal a few years later (1974).
} 
Symposium', together with E. W. Gerber in 1979. There, Gerber's field division was kept from the first edition: (1) nature of sport, (2) metaphysics of sport, (3) embodiment in sport, (4) ethics and sport, and (5) aesthetics and sport (Gerber, 1972). Thus, Morgan inherited and kept this division in his later anthologies, just with the addition of social-political considerations. The most important change that he made was including new sports-philosophical works written after 1972 instead of the previous. In this regard, he included 15 new articles in 1979, or $30 \%$ of the book content, which replaced the presports-philosophical ones. By that, Morgan actually started the purification process within the literature. Moreover, with each edition the percentage was getting higher: in $1987-70 \%, 1995-74.5 \%$, $2001-97 \%$, until he finished the whole process in the 2007 edition of the 'Ethics in Sport' which is the first $100 \%$ sports-philosophical anthology.

The contours of the ethics of sport, as well as the first field-divisions, can be detected already in the first edition of Philosophic Inquiry of Sport (Morgan \& Meier, 1987). There, the ethics of sport is still an integral part of more general (sixfold) philosophy of sport. Later, in his new anthology books (Morgan, Meier, \& Schneider, 2001; Morgan, 2007; Morgan, 2017), Morgan will extract and keep the ethical part to which he will be referring to as "the ethics in sport"-a specific field or branch of philosophy of sport. In 1987, Morgan uses a threefold division of the ethics of sport, namely: (1) sportsmanship, cheating and deception or sports competition issues in sport; (2) women in sports or gender issues in sport; and (3) drugs and sports or issues of performance enhancements (see Table 1).

Importantly, in the same edition, to set the proper grounds for arguing and reflecting about moral problems in sport and ethical (normative) conceptions of sport, Morgan went to the metaphysics and/or nature of sports, looking for the roots in the philosophy of sport. In this regard, while he is leaning on B. H. Suits understandings and definitions of sport (game and play), and while he is actually pointing out to Suits work as a thoroughgoing for the philosophy of sport, it seems to me that Morgan's understanding of the philosophy of sport is--"suitsain".

In the $2^{\text {nd }}$ edition (Morgan \& Meier, 1995), he enriched the previous division with the topic of animals in sport (The Morality of Hunting and Animal Liberation), which he kept in the first edition of the Ethics in Sport (Morgan, Meier, \& Schneider, 2001). Also, in the 1995 edition he included two basic articles by D'Agostino (1981) and Morgan (1987) which will lead to developing of normative conceptions of formalism, conventionalism and internalism in sport (see Table 1).

Furthermore, in Handbook of Sports Studies (Coakley \& Dunning, 2000), while presenting the (over)view of the philosophy of sport and describing the ethics in sport, Morgan stuck to the previous division, just making a small change through secluding the topic of cheating and sportsmanship as two separate 'clusters' from the competition. Also, he stated that all ethical considerations of sport derived from two basic questions: (1) how should athletes treat one another, and (2) how should athletes comport themselves, individually and collectively, in their pursuit of athletic excellence? (Morgan, 2000: 208-209).

Interestingly, only a year after, in the first edition of the Ethics in Sport (2001), he made two changes. One, he handed back topics of cheating and sportsmanship among competition issues in sport. And two, he introduced final cluster of topics named social issues in the ethics of sport (see Table 2). Morgan states that this is the field of questioning whether the sport is good for society, especially in comparison with all other elements of society (Morgan, Meier \& Schneider, 2001: xi), and the field of consideration of ethical issues in sport that implicates larger social context (Morgan, 2017: 397). Within this field, he included a wide range of topics: violence as such and in boxing, patriotism and nationalism, disability (Morgan, Meier, $\&$ Schneider, 2001); violence, exploitation, race,

Table 1. W. J. Morgan's field division of the Ethics of Sport in 1979, 1987 and 1995 anthologies

\begin{tabular}{|c|c|c|c|}
\hline Anthology & $\begin{array}{c}\text { Gerber, E. W. \& Morgan, } \\
\text { W. J. (eds.) } \\
\text { Sport and the Body: a } \\
\text { Philosophical Symposium } 1979 \\
2^{\text {nd }} \text { edition }\end{array}$ & $\begin{array}{l}\text { Morgan, W. J. \& } \\
\text { Meier, K. V. } \\
\text { Philosophic Inquiry in Sport } \\
1987\end{array}$ & $\begin{array}{c}\text { Morgan, W. J. \& } \\
\text { Meier, K. V. } \\
\text { Philosophic Inquiry in Sport } \\
1995 \\
2^{\text {nd }} \text { edition }\end{array}$ \\
\hline Chapter & V. Sport and Value - Oriented & IV. Sport and Ethics & IV. Sport and Ethics \\
\hline Field division & $\begin{array}{l}\text { No field division. Topics included: } \\
\text { - Deception } \\
\text { - Sportsmanship } \\
\text { - Competition } \\
\text { - Utilitarianism } \\
\text { - The Kantian Imperative and } \\
\text { Hegelian Sittlichkeit }\end{array}$ & $\begin{array}{l}\text { 1. Competition, Sportsmanship, } \\
\text { Cheating, and Failure } \\
\text { 2. Drugs and Sport } \\
\text { 3. Women and Sport }\end{array}$ & $\begin{array}{l}\text { 1. Competition, Sportsmanship, } \\
\text { Cheating } \\
\text { 2. Drugs and Sport } \\
\text { 3. Gender Issues and Sport } \\
\text { 4. The Morality of Hunting and } \\
\text { Animal Liberation }\end{array}$ \\
\hline
\end{tabular}


spectatorship, admiration, and disability (Morgan, 2007); racism, spectatorship, and politics (Morgan, 2017). Third, he added the third basic question: (3) how should sport be morally evaluated from the larger standpoint of society? (Morgan, Meier, \& Schneider, 2001, ix)

The last change in the contours and divisions he made was removing 'animal issues in sport' (Morgan, 2007, 2017) without explanation or consideration of future inclusion of the specific area. ${ }^{2}$ However, with this change, the ethics of sport finally got its fourfold field division that I call simply Morgan's division:

(1) competition issues include topics of winning, cheating, intentional/strategic rule violation, gamesmanship, sportsmanship, and fair play

(2) enhancement issues include issues of doping and anti-doping, drug testing, gene-doping, and enhancement technology

(3) gender issues include problems of women in sport, sex, and gender equ(al)ity, sexuality, male domination, sexual discrimination, and mixed competition

(4) social issues include violence, disability, politics, race, patriotism, admiration of heroes, exploitation, supporting the teams, and sporting boycotts.

In conclusion to this part, I will emphasise three things. First, through the extraction of ethical issues in sport from the wider sports-philosophical context, Morgan has acknowledged that, in his view, the ethics of sport is the most important field and sub-discipline of the philosophy of sport, where key issues of and for the contemporary sport, as well as its integrity, are being debated and resolved. Even more, the importance of ethical issues for today sports is present implicitly but still quite obviously in the third part of the Routledge Handbook of the Philosophy of Sport where most of »Key issues and themes in the philosophy of sport « (McNamee \& Morgan, 2015: 285-439) are in fact (bio-)ethicalnamely: competition, disability and Paralympic sport, doping, fair play, genetics, spectatorship, commercialisation, and technology in sport.

Second, the introduction article "Ethics, Ethical Inquiry, and Sport: An Introduction" (Morgan, 2007: xiii-xxxvii; 2017, 1-26) is extremely important and helpful. Moreover, I find it necessary because of the many scholars' sake (including myself) that were not educated and raised in the Anglo-Saxon tradition and/or educational system. Thus, by such an introduction, it is absolutely clear to which ethics and ethical tradition and interpretation the author is referring to and leaning on in building new and specific ethics (of sport).

Finally, it is obvious that Morgan's division derives from wide and deep conversance of the ethics of sport literature together with more than a decade of thorough in-depth analysis, consideration, revision, and evaluation of the content of the fields. This is what gives it deep foundation, strength, and plausibility, as well as explanation to its continuance and longevity.

\section{Influence and impact of Morgan's division}

Morgan's edited anthology (together with K. V. Meier) Philosophical Inquiry in Sports (1987, 1995) has become the "standard text in the field for a quarter of a century" (Durbin, Loland, \& McNamee, 2018: 2). This was the first anthology in the philosophy of sport (Fairchild, 1988: 71; McNamee, 2007: 1), and it helped the "advance

Table 2. Field division in W. J. Morgan's Ethics in Sport (2001, 2007, 2017)

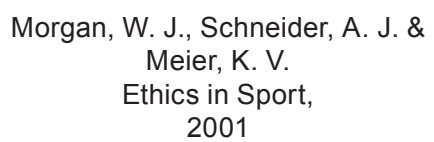

Morgan, W. J.
Ethics in Sport,
2007

$2^{\text {nd }}$ edition

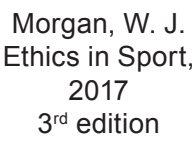

1. Fair Play, Being a Good Sport, and Cheating: At What Price Victory?

2. The Limits of Being Human: The Case of PED

3. Women in Sport: Gender Equity and Gender Identity

4. Animals and Their Use in Sport: Where Do We Draw the Moral Line?

5. The Social Ethics in Sport: Is Sport Good for Society?
1. Metaethical Consideration of Sport

2. Competition and Fair Play: Considerations of Winning, Cheating, and Gamesmanship

3. The Limits of Being Human. Doping and Genetic Enhancement

4. Gender and Sexual Equality in Sport

5. Select Issues in the Social Ethics of Sport: Violence, Exploitation, Race, Spectatorship, and Disability
1. Nature of Sport

2. Competition and Fair Play: Considerations of Winning, Cheating, and Gamesmanship

3. The Limits of Being Human. Doping and Genetic Enhancement

4. Gender and Sexual Equality in Sport

5. Select Issues in the Social Ethics of Sport: Racism, Spectatorship, and Politics

\footnotetext{
2 At the $1^{\text {st }}$ International Conference Ethics, Bioethics and Sport in Croatia (23 ${ }^{\text {rd }}$ and $24^{\text {th }}$ March, 2018, Zagreb and Varaždin), I personally asked Morgan why he did that, and he said that it did not seem as an important topic at that point, which he explained later in two ways: first, because of the several responses from the authors while preparing the edition that the 'animal and sports' issue was only one of marginal interest; and second, that some 'animal and sports' essays elicited several critical comments from readers to the effect they were not solid essays.
} 
of sport philosophy as an academic subject" and "become the standard anthology for philosophy of sport classes, and attract scholars to the study of sport from a philosophical perspective" (ibid., 79). Moreover, it made an international impact in initiating and developing the philosophy of sport in Chinese speaking regions (Hsu, 2010: 238-239), the Netherlands and Belgium (van Hilvoorde, Vorstenbosch, \& Devisch, 2010: 228-229), and Germany (Pawlenka, 2010: 280) ${ }^{3}$.

In regard to Morgan's impact and influence over the field, I find J. S. Russell's note significant and beautiful:

No one has done more than Bill Morgan to create a presence for philosophy of sport as a subject of serious intellectual inquiry. He was there as one of the earliest leaders and contributors to the discipline. In addition to his published work that has covered many topics with deft insight and wit $[. .$.$] he quickly took on a role$ as a promoter of the discipline. I am confident that Bill's anthologies, especially the early ones (edited with Klaus Meier), did as much, and probably more, to put philosophy of sport on the map as any monographs. They expertly chose and reviewed the most substantial work that had been done and drew the interest of scholars and created opportunities for students to study in this area. From that point, a discipline emerged and began to flourish. (Russell, 2018: 453)

It seems to me that Morgan's influence in the field is visible and recognisable most in shaping the contours and division of the Ethics of Sport. In that regard, I took what seems to be the (seven) most considered and most accepted editions of the ethics in/of sport in the field-four authors books by Simon $(1991,2004,2010)$ and Simon, Hager, and Torres (2015), and three edited anthologies by McNamee and Parry (1998), Boxill (2003), and McNamee (2010). I extracted their field division and compared it to Morgan's (see Tables 3 and 4). Here is what I found.

First, all editions are using divisions very similar to (if not the same as) Morgan's: 1) Simon (Hager and Torres): competition/sportsmanship/ fairness, enhancements, gender, commercialisation, education, intercollegiate sports; 2) McNamee and Parry: fair play, education, contemporary issues (cheating, violence...); 3) Boxill: education, sportspersonship, competition, doping, violence, gender, racism, and role models; 4) McNamee: fair contest, enhancement and genetic modifications, cultures of equality and difference, ethical development in and through sports (rules, virtues and vices), commercialism, corruption and exploitation, adventurous activities. Interestingly, only McNamee (besides
Morgan) included a chapter on the roots of sport, game, and play, which seems to be the necessary foundation for constructing (any kind) of ethics of sport. Namely, it seems only scientifically just that in order to build proper, accurate and plausible field-specific ethics, one should first have deep and comprehensive understanding and knowledge of the field, its roots and essential foothold, and especially its specific moral issues, problems and dilemmas.

Second, differences that can be detected are threefold: (1) in usage of education as another field (which I will refer to later); (2) in McNamee's inclusion of adventurous activities (skydiving, climbing, mountaineering, BASE jumping) which are just "extend of the often narrow fare of examples in sport ethics" (McNamee, 2010: 437); (3) in secluding some (subordinated) topics from their superordinate (or umbrella) ones, and putting more emphasis to such topics through giving them a separate chapter: violence (Boxill, McNamee), cheating (Simon), economy issues (McNamee, Simon), fair play and sportspersonship (Boxill, McNamee, and Parry, Simon), and racism (McNamee, Simon). Despite the differences, all of them fit well in Morgan's division.

Third, through his editions, Morgan provided a simple, clear, accurate and plausible framework for the whole sports-philosophical community and by that in a large amount shaped the contours and divisions of the ethics of sport. If we look at Table 2 and compare it to Table 3, we can find it even more visible.

Summa summarum, the fact is that Morgan was the first one to introduce the fourfold division of the ethics of sport in the literature. Hence, he was the first to introduce also the fifth-animals in sport, and again was the first to exclude it. Other authors and scholars by large followed it. And it seems that they still do. Seven books that I have singled out are the obvious proof of that. Moreover, some editors even included the same articles that Morgan extracted as crucial or the most important in the field (cf. English, Simon, Brown, Kretchmar, Dixon...). Finally, in all of the seven books, at some point, the authors acknowledged importance and influence of Morgan's work in general and edited anthologies in particular, which can be traced in references and quotations, as well as in including Morgan's articles and viewpoints.

\section{Why did he propose such a division in the first place?}

What seems to be the core question of my investigation in the history of the discipline is why did Morgan propose such a division in the first place? And the answer to that question is, I believe, the

Hence, it was the first book that we got in Croatia. It had a significant and crucial impact on the first scholars dealing with philosophical and ethical considerations on sport. 
Table 3. Field divisions in R. L. Simon's editions (1991, 2004, 2010, 2015 - with Hager and Torres)

\begin{tabular}{|c|c|c|c|}
\hline $\begin{array}{c}\text { Simon, R. } \\
\text { Fair Play: Sports, Values } \\
\text { and Society } \\
1991\end{array}$ & $\begin{array}{l}\text { Simon, R. } \\
\text { Fair Play: The Ethics of Sport } \\
2004\end{array}$ & $\begin{array}{l}\text { Simon, R. } \\
\text { Fair Play: The Ethics of Sport } \\
2010\end{array}$ & $\begin{array}{l}\text { Simon, R. L., Torres, C. R \& } \\
\text { Hager, P. F. } \\
\text { Fair Play: Sports, Values and } \\
\text { Society } \\
2015\end{array}$ \\
\hline $\begin{array}{l}\text { 1. Introduction in } \\
\text { Philosophy of Sports } \\
\text { 2. The Ethics of } \\
\text { Competition } \\
\text { 3. Cheating and Violence in } \\
\text { Sport } \\
\text { 4. Enhancing Performance } \\
\text { Through Drugs } \\
\text { 4. Equality and Excellence } \\
\text { in Sport } \\
\text { 5. Do Intercollegiate } \\
\text { Athletics Belong to } \\
\text { Campus } \\
\text { 6. Sport and Social Values }\end{array}$ & $\begin{array}{l}\text { 1. Competition a Mutual } \\
\text { Quest for Excellence } \\
\text { 2. Sportsmanship } \\
\text { 3. Drugs and Violence } \\
\text { 4. Racial Differences } \\
\text { 5. Inner Morality of Sport }\end{array}$ & $\begin{array}{l}\text { 1. Competition in Athletics: } \\
\text { Is It Morally Defensible? } \\
\text { 2. Sportsmanship, Fairness } \\
\text { and Competition in Sport } \\
\text { 3. Drugs, Genes, and } \\
\text { Enhancing Performance } \\
\text { in Sport } \\
\text { 4. Gender Equity in Sport: } \\
\text { What does Justice } \\
\text { Require } \\
\text { 6. Sports on Campus: } \\
\text { Intercollegiate Sports } \\
\text { and Their Critics } \\
\text { 7. The Commercialization } \\
\text { of Sport: Marketing } \\
\text { and Corruption in } \\
\text { Competitive Athletics } \\
\text { 8. Sport, Moral Education, } \\
\text { and Social Responsibility }\end{array}$ & $\begin{array}{l}\text { 1. Introduction: The ethics of } \\
\text { sport } \\
\text { 2. Theories of Sport: } \\
\text { Frameworks for evaluation } \\
\text { 3. Ethics in Competition: } \\
\text { Cheating, Good Sports and } \\
\text { Tainted Victories } \\
\text { 4. Drugs, Genes, and } \\
\text { Enhancing Performance in } \\
\text { Sport } \\
\text { 5. Gender Equity n Sport: What } \\
\text { does Justice Require? } \\
\text { 5. Sport on Campus: } \\
\text { Intercollegiate Sports and } \\
\text { Their Critics } \\
\text { 6. The Commercialization } \\
\text { of Sport: Marketing and } \\
\text { Corruption in Competitive } \\
\text { Athletics } \\
\text { 7. Sport, Moral Education, and } \\
\text { Social Responsibility }\end{array}$ \\
\hline
\end{tabular}

Table 4. Field division in McNamee and Parry (1998), McNamee (2010) and Boxill (2003) anthologies

\begin{tabular}{|c|c|c|}
\hline $\begin{array}{c}\text { McNamee, M. J. \& Parry, S. J. (Eds.) } \\
\text { Ethics and Sport } \\
1998\end{array}$ & $\begin{array}{l}\text { McNamee, M. J. (Ed.) } \\
\text { Ethics of Sport: A Reader } \\
2010\end{array}$ & $\begin{array}{l}\text { Boxill, J. M. (Ed.) } \\
\text { Sports Ethics: An Anthology } \\
2003\end{array}$ \\
\hline $\begin{array}{l}\text { 1. Ethics and Sport } \\
\text { 2. Fair Play and Sporting Behaviour } \\
\text { 3. Physical Education and Sports } \\
\text { Coachingllen } \\
\text { 4. Contemporary Ethical Issues in } \\
\text { Sports: } \\
\text { - Multinational Sport } \\
\text { - Violence and Aggression } \\
\text { - Cheating and Self-deception } \\
\text { - Private Autonomy and Public } \\
\text { Morality } \\
\text { - Heidegger and Sport }\end{array}$ & $\begin{array}{l}\text { 1. The Roots of Sport Ethics: Games, Play, } \\
\text { Sports } \\
\text { 2. Fair Contest: Rules, Spoiling and Cheating } \\
\text { 3. Doping, Genetic Modification and the Ethics } \\
\text { of Enchancement } \\
\text { 4. Cultures of Equality and Diference } \\
\text { 5. Dis/Ability, Gender, Race } \\
\text { 6. Ethical Development In and Through Sport: } \\
\text { Rules, Virtues and Vices } \\
\text { 7. Commercialism, Corruption and Exploitation } \\
\text { in Sports } \\
\text { 8. Ethics and Adventurous Activity }\end{array}$ & $\begin{array}{l}\text { 1. Sport and Education } \\
\text { 2. Sport and Sportpersonship } \\
\text { 3. Sport and Competition } \\
\text { 4. Sport and Drugs } \\
\text { 5. Sport and Violence } \\
\text { 6. Sport and Gender } \\
\text { 7. Sport and Racial Issues } \\
\text { 8. Sport and Role Models }\end{array}$ \\
\hline
\end{tabular}

central and most powerful rationale for my claim about Morgan.

It seems to me that Morgan was a careful watcher of what was happening within the discipline, capturing and shaping it the way it occurred, and following the course that the discipline took, acknowledging the state of the affair. In other words, he did not invent his division separately as a sort of a model, alienate to the discipline, trying to force it over or upon the discipline and making sure that everything fit in, but the other way around. He accepted and respected the growth and development of the discipline, carefully evaluating the sport-philosophy literature corpus, and then putting things in their place by making a framework out of groups of topics in the most logical, precise and clear manner. More so, thanks to his aptitude and capacity, he was able to recognize the contours and divisions in the ethics of sport - which I call Morgan's division-and was the first to present them in his anthologies.

Thus, his role in the sub-discipline development seems to be twofold - being at the same time the inner part of its growth as an author and literature contributor, on one hand, and, at the same time on the other, a curious and interested reader of the published work of others and a sort of outer discipline editor inclining to objectively value the literature and put everything in place where it belongs. Precisely that is the reason for the strength and steadiness of Morgan's division over the decades, as well as an explanation why it is widely spread and excepted throughout the literature. 


\section{Possible objections}

In this section, I will answer four groups of possible objections. The first group makes the ones asking should have Morgan done it differently, second group are objections directed to what is missing in the division, third are questions regarding authorship, and fourth are objections that are going over the disciplinary edge and actually belongs to the different sub-discipline.

\section{Should has not Morgan done it differently?}

(1) Should cheating, fair play, and sportsmanship be secluded from the competition? My answer is no, despite different editions where one can find topics of fair play (McNamee \& Parry, 1998; McNamee, 2010), cheating (Simon, 1991) and sportsmanship (Boxill, 2003; Simon, 2010) having their own chapters. If we look closely, all of the editions derive from the understanding of sport as a competition, and these chapters are just making more emphasis on specific instances within the competition or contest cluster of issues.

(2) Social issues in the ethics of sport could raise many objections going in several directions. One can underlie what issues are missing or propose what topics should be included. Others can object that Morgan has excluded some extremely important and relevant topics from previous editions, for instance, disability, violence, or exploitation of young (student) athletes. Some might also object that some topics (or each and every one for that matter) should be considered as a special field with the more detailed and dedicated approach, deserving a special chapter.

It seems to me that Morgan did not put (careful) enough consideration on what is a part of this field and what should be included as the most important or significant. Hence, he did not even define or describe it precisely. Moreover, edition by edition he was changing the content in an amount that a single topic was not included in all of the three at the same time. On the other hand, Morgan was right to introduce the field of 'social ethics' in sport, and all of the topics included are de facto social issues in sport.

The problem here is, firstly, that 'social ethics' is an extremely wide field, much wider than the other three in Morgan's division. Secondly, the field needs its definition or conceptualization, which will make a clear distinction between what is or is not a part of it. Thirdly, further divisions in the specific field need to be done. Fourthly, the methodology should be established before, or argumentative explanations after, careful selection of the representative articles for anthologies.

Thus, I do not welcome McNamee's seclusion of the topics of commercialism, corruption and exploitation in sports, dis/ability and race, cultures of equality and difference; Simon's of marketing and corruption; and Boxill's of violence, racism, and role models, and intercede on including them under the umbrella field or category of social issues in the ethics of sport. It seems to me that putting and keeping things at the proper place in the discipline, right under the umbrella that they belong to, would be scholarly justified and plausible thing to do.

Furthermore, gender issues in sport are social issues per se, and they should be placed in the proper category. The same goes for the animal issues, if we take those to be a part of the ethics of sport.

\section{What is missing?}

(1) Animals in sport. In my opinion, this important topic is heavily neglected in the literature, where I was able to detect only one article (in two parts) in Sport, Ethics and Philosophy by J. Ilundáin-Agurruza (SEP, Part 1: 3/2007: 325-345; Part 2: 1/2008: 18-38), and only three articles in Journal of the Philosophy of Sport by M. L. Wade on animal liberation and sport hunting (JPS, 17/1990: 15-27), M. Kheel's ecofeminist critique of hunting (JPS, 23/1996: 30-44), B. E. Rollin's piece on rodeo (JPS, 23/1996: 1-9), and D. Inglis on Ortega y Gasset's philosophy of sportive existence (JPS, 31/2004: 78-96).

(2) Virtues in sport. Despite the fact that Morgan is talking about the field of aretaic or virtue ethics in his introduction, and that virtues are mostly being considered in the context of (moral) education, he unduly found no place for any article in that regard, not even for a brilliant $\mathrm{J}$. S. Russell's peace on resilience (Russell, 2015). I agree with McNamee's disappointment in that regard (McNamee, 2003: 184) and do believe that careful consideration needs to be done so the proper place would be found for the topic of virtues in sport.

(3) Jurisprudence in sport. The work by Russell, Simon, Dixon, and Berman that connect the issue of adjudication in sport to moral values definitely deserves its place in the anthologies. This omission is somehow even more surprising because Morgan was JPS editor for the publication or preparation of the first two of Russell's articles (in 1997 and 1999).

\section{The authorship}

(1) What about Simon's division from 1991? Simon presented a fourfold division (actually, fivefold if we include typically American topic of intercollegiate sport, which I do not, simply because it is not applicable for most of the planet) in the $1^{\text {st }}$ edition of Fair Play. Sports, Values and Society: competition; cheating and violence; enhancements; equality and excellence in sport; and intercollegiate sport. I will respond to that in three ways. First, Simon's book was 
published after Morgan had presented his threefold division in 1987. Also, Morgan's division is much more precise. Namely, cheating is a part of competition issues and violence is a social issue, while the question of general equality is not just gender or sex issue. Second, Simon left this division for the different one in the $2^{\text {nd }}$ edition in 2004, while in the $3^{\text {rd }}$ (Simon, 2010) he used what I call Morgan's division. Finally, Simon's book is authors book, while Morgan's is edited anthology. That means Morgan's division comes from an extremely large discipline literature overview and careful field examination, which gives him a quite different viewpoint and global perspective for detecting outer contours and establishing inner divisions of the ethics of sport.

However, one can object using post hoc ergo propter hoc ("with this, therefore because of this") or post-hoc fallacy. Namely, the fact that Morgan was the first to introduce the division to the discipline might not mean that there is a consequent connection between him and aforementioned authors. It is almost impossible to overpass such an objection (even if one goes through the content analysis) if the authors did not make a clear specific statement on influence or co-opting.

(2) What about the role of the other editors? It was not my intention to underestimate K. V. Meier or A. J. Schneider in any way, despite the fact that I actually did it by putting focus on Morgan alone. Moreover, I did not put any scope on Meier's or Schneider's contributions, I intentionally left it for other researche(r)s. However, in my defence, Morgan is the first editor in all of the editions, which means that his role and responsibility is a bit more essential or decisive.

\section{Going over the discipline}

(1) Should has not he included education in ethics of sport, like Simon (2010, 2015), McNamee and Parry (1998) or Boxill (2003)? I believe there are two main answers to that. First, philosophy of education is a separate sub-discipline, even when we are talking about ethics, education, and sport. Second, Morgan was working with students for decades, thus it is not surprising that all of his editions are highly educational. On the one hand, they give precise in-depth information on and orientation in and of the field, its contours and divisions with the highest quality content. On the other hand, all "the essays have been carefully selected with pedagogical utility in mind" and possible usage in the curricula (McNamee, 2003: 182). The last edition has made even more emphasis in that regard, posing questions at the end of each essay, providing a guiding hand, and clearly directing to the essence. It seems to me that all the presented, accompanied with rich Morgan's explanatory and introductory parts (24 pages altogether, which can be read as a separated text) gives enough educational guidance and materials. Thirdly, the most obvious fact is that even in the capital editions of Routledge Handbook (McNamee \& Morgan, 2015) or Bloomsbury Companion (Torres, 2014) education was not included within the sports-philosophical branches. More so, JPS and SEP included just a small amount of articles on the topic, most of them by Peter J. Arnold.

(2) Genetics is (almost) non-present. This is an objection that M. McNamee made already in the review of the $1^{\text {st }}$ edition of the Ethics in Sport stating that attention should be paid to genetic-manipulation strategies and techniques (McNamee, 2003: 184). Certainly, Morgan did not pay much attention to genetics, but it seems to me that it does not change anything in his division. On the other hand, genetics and sport belong to another sub-discipline-bioethics of sport and needs an interdisciplinary approach with extensive empirical research and data.

\section{A few critical notes on the Morgan's division}

Firstly, in the introduction article to the $2^{\text {nd }}$ and $3^{\text {rd }}$ edition of the Ethics in Sport Morgan is describing his understanding of the (general) ethics as deontological, consequential/utilitarian, aretaic and contractarian (Morgan, 2007; 2017). I stated earlier that I greet such a presentation of what ethics is in terms of different education in and understanding of general ethics in different philosophical traditions. However, in the specific context and the content of the books, such an introduction seems to be displaced and unnecessary because Morgan does not show how or even that he is in any way guided by it. More so, he did not manifest its usage in ethical and moral considerations of sport or was building a connection to it anywhere in the book. And there are some great opportunities. Hence, he is not even mentioning it again. It is even more pity when there is no discussion on one hand, or, on the other, building a part of the ethics of sport from the viewpoint of the virtues or virtue ethics, utilitarianism, deontology, or contractarianism.

Secondly, there is the issue of Morgan's editor choices and their plausibility that influence both the ethics of sport sub-discipline and its development as well as the structure, content, and quality of the anthologies. On one hand, Morgan alone is including/excluding several topics, authors, and articles in the anthologies how he sees fit, without explanation and/or discussion about it. On the other hand, which seems even more challenging, Morgan 
developed a practice of inviting or ordering original articles on specific topics from the selected scholars. In the literature there is no critical analysis in that regard, and one can assume that most of the scholars are in agreement with his choices and/or insertions. Finally, through the mentioned practices, Morgan is actually emphasizing and/or de-emphasizing certain topics in the field.

Thirdly, there is the issue of the (established) contours and divisions per se. In this regard, it seems to me that Morgan's division of the ethics of sport is actually twofold, basically divided into two parts. The first one, I will call it Normative Aspects of the ethics of sport, is descriptive and prescriptive at the same time, with the final aim of building a normative theory that could provide guidance for all sports practitioners. That part would include articles thematising normative issues and normative conceptions in the ethics of sport: formalism, conventionalism, internalism/interpretivism. (Morgan 2007; 2017).

The second one, that I will call Practical Aspects of the ethics in sport, has a threefold division. In this part, three large groups of practical moral problems in sport are being considered, discussed, and debated. Namely, moral issues regarding sports competition, different kinds of performance enhancements and a wide range of problems in the social realm of sport.

Thus, it seems to me that plausible and correct division of the ethics of sport should look like this:

(1) Normative Aspects

- Formalism

- Conventionalism

- Internalism and interpretivism (broad, conventionalist, pluralistic, shallow)

(2) Practical Aspects

- Competition

- Enhancements

- Social Ethics

To sum up, it seems that the presented framework in a precise and plausible way captures contours and divisions of the ethics of sport in the literature thus far. Nevertheless, as an extremely wide (enough) umbrella framework, at the same time it opens up numerous opportunities for further development through creating new sub-divisions for the consideration of the broad range of topics and problems within the realm of sport.

\section{Possibilities for future discussion}

There are several other ways to address and critically assess Morgan's work in the field of philosophy and ethics of sport. In this paper focus was on Morgan's influence on shaping the contours of the ethics of sport, while several other points were not touched, mentioned or analysed, and it seems that they should be discussed in the future.

Firstly, the issue of Morgan's editor choices and developing sense of what is and is not important in our field needs a closer critical look. Secondly, his influence on the field in terms of putting focus on and emphasizing development of certain topics or areas could be also investigated, as well as what he dropped out along the way. Furthermore, the question how much of this is Morgan's own effort at framing and how much of it is just a product of him reflecting what was being published that was interesting and new can be addressed.

\section{To summarize}

Three remarks about Morgan and his work should be pointed out at the end. On one hand, Morgan edited first anthologies in the discipline, which helped in the global recognition and development of the philosophy and ethics of sport. On the other hand, he organized and inserted the fourfold frame in the ethics of sport as follows: 1) competition and fair play, (2) human enhancements, (3) gender issues, and (4) social issues. This frame was widely accepted in the field and used as a sort of default by many authors in different books and editions. Finally, in his anthologies, he introduced, promoted, and emphasised original work in the field of philosophy and ethics of sport. Moreover, he supported and put the light on many topics, scholars, articles, and books that were not perceived as important or as valuable before.

To conclude, with this article I wanted to bring some more clarity in the development of the ethics of sport, as well as into a role of certain scholars in that regard, but also to instigate further discussion and investigations in similar directions.

\section{References}

Boxill, J. (Ed.) (2003). Sports Ethics: An anthology. Oxford: Blackwell.

Coakley, J., \& Dunning, E. (Eds.) (2000) Handbook of Sports Studies. London: SAGE Publications Ltd.

D'Agostino, F.(1981). The ethos of Games. Journal of the PhilosophyofSport, 8(1), 7-18. doi: 10.1080/00948705.1981.9714372

Durbin, D., Loland, S. \& McNamee, M. (2018). Morgan and the sporting life. Sport, Ethics and Philosophy, ahead of print. doi: 10.1080/17511321.2018.1535523

Fairchild, D.L. (1987). Philosophic inquiry in sport. Journal of the Philosophy of Sport, 14(1), 71-79. doi: 10.1080/00948705.1987.9714454

Fraleigh, W. (1984). Right actions in sport. Ethics for contestants. Champaign, IL: Human Kinetics. 
Gerber, E.W. (Ed.) (1972). Sport and the body: A philosophical symposium. Philadelphia: Lea \& Febiger.

Gerber, E.W. \& Morgan, W.J. (Eds.) (1979). Sport and the body: A philosophical symposium (2 ${ }^{\text {nd }}$ ed.). Philadelphia: Lea \& Febiger.

Hsu, L. (2010). An overview of sport philosophy in Chinese-speaking regions (Taiwan \& Mainland China). Journal of the Philosophy of Sport, 37(2), 237-252. doi: 10.1080/00948705.2010.9714779

Lumpkin, A., Stoll, S.K. \& Beller, J. (1994). Sports ethics: Applications for fair play. St. Louis, MO: Mosby-Year Book.

McNamee, M. (2003). Ethics in sport. Edited by William J. Morgan, Klaus V. Meier, and Angela J. Schneider. Published 2001 by Human Kinetics, Champaign, IL. Journal of the Philosophy of Sport, 30(2), 182-184. doi: 10.1080/00948705.2003.9714644

McNamee, M. (2007). Sport, ethics and philosophy; context, history, prospects. Sport, Ethics and Philosophy, 1(1), 1-6, doi: 10.1080/17511320601173329

McNamee, M.J. (Ed.) (2010). Ethics of sport: A reader. London: Routledge.

McNamee, M. \& Morgan, W.J. (Eds.) (2015) Routledge Handbook for the Philosophy of Sport. London: Routledge.

McNamee, M.J., \& Parry, S.J. (Eds.) (1998). Ethics and sport. London: Routledge.

Morgan, W.J. (1973). An existential phenomenological analysis of sport as a religious experience. In R.G. Osterhoudt (Ed.), The philosophy of sport. A collection of original essays (pp. 78-107). Springfield, IL: Charles C. Thomas - Publisher.

Morgan, W.J. (Ed.) (2007). Ethics in sport ( $2^{\text {nd }}$ ed.). Champaign, IL: Human Kinetics.

Morgan, W. J. (Ed.) (2017). Ethics in sport ( $3^{\text {rd }}$ ed.). Champaign, IL: Human Kinetics.

Morgan, W.J. (2000). The philosophy of sport: A historical and conceptual overview and a conjecture regarding its future. In J. Coakley \& E. Dunning (Eds.), Handbook of sports studies (pp. 204-213). London, Thousand Oaks, New Delhi: SAGE Publications.

Morgan, W.J. \& Meier, K.V. (Eds.) (1987). Philosophic inquiry in sport. Champaign, IL: Human Kinetics.

Morgan, W.J. \& Meier, K.V. (Eds.) (1995). Philosophic inquiry in sport (2 ${ }^{\text {nd }}$ ed.). Champaign, IL: Human Kinetics.

Morgan, W.J., Meier, K.V., \& Schneider, A.J. (Eds.) (2001). Ethics in sport. Champaign, IL: Human Kinetics.

Morgan, W.J. (2020). Sport and moral conflict: A conventionalist theory. Philadelphia: Temple University Press.

Osterhoudt, R.G. (Ed.) (1973). The philosophy of sport. A collection of original essays. Springfield, IL: Thomas.

Pawlenka, C. (2010). Philosophy of sport in Germany: An overview of its history and academic research. Journal of the Philosophy of Sport, 37(2), 271-291. doi: 10.1080/00948705.2010.9714781

Russell, J.S. (2018). A critique of conventionalist broad internalism. Sport, Ethics and Philosophy, 12(4), 453-467. doi: $10.1080 / 17511321.2018 .1497079$

Rusell, J.S. (2015). Resilience. Journal of the Philosophy of Sport, 42(2), 159-183. doi: 10.1080/00948705.2015.1009838

Simon, R. (1991). Fair play. Sports, values and society. Boulder, CO: Westview Press.

Simon, R. (2004). Fair play. The ethics of sport. Boulder, CO: Westview Press.

Simon, R. (2010). Fair play. The ethics of sport. Boulder, CO: Westview Press.

Simon, R.L., Torres, C.R. \& Hagar, P.F. (2015). Fair play: Sports, values and society. Boulder, CO: Westview Press

Škerbić, M.M. (2020). Internal values of sport and bio-technologized sport. Philosophies, 5(4), 26. doi: 10.3390/ philosophies5040026

Škerbić, M.M. (2019). Etika sporta Williama J. Morgana. [William J. Morgan's Ethics of Sport. In Croatian.] (Unpublished doctoral dissertation, University of Zagreb). Zagreb: Faculty of Humanities and Social Sciences of the University of Zagreb, Croatia.

Škerbić, M.M. (2017). Ethics of sport: Contours and divisions of a discipline. In B. Savović, R. Mandić \& S. Radenović (Eds.), Conference Proceedings, International Scientific Conference Effects of Physical Activity Application to Anthropological Status with Children, Youth and Adults (pp. 63-69). Belgrade: University of Belgrade, Faculty of Sport and Physical Education Press.

Van Hilvoorde, I., Vorstenbosch, J., \& Devisch, I. (2010). Philosophy of sport in Belgium and the Netherlands: History and characteristics. Journal of the Philosophy of Sport, 37(2), 225-236. doi: 10.1080/00948705.2010.9714778

Submitted: December 8, 2020

Accepted: October 22, 2021

Published Online First: December 10, 2021

Correspondence to:

Assist. Prof. Matija Mato Škerbić, Ph.D.

Department of Philosophy and Culture

Faculty of Croatian Studies, University of Zagreb

Borongajska cesta 83d, 10000 Zagreb, Croatia

Phone: 0038598349843

Email: mskerbic@hrstud.hr 